\title{
Amyas Griffith: A Chequered Career
}

\section{Author(s): J. F. Fuller}

Source: Kerry Archaeological Magazine, Vol. 3, No. 15 (Oct., 1915), pp. 162-175

Stable URL: http://www.jstor.org/stable/30059738

\section{Accessed: 19-06-2016 19:33 UTC}

Your use of the JSTOR archive indicates your acceptance of the Terms \& Conditions of Use, available at

http://about.jstor.org/terms

JSTOR is a not-for-profit service that helps scholars, researchers, and students discover, use, and build upon a wide range of content in a trusted digital archive. We use information technology and tools to increase productivity and facilitate new forms of scholarship. For more information about JSTOR, please contact support@jstor.org. 

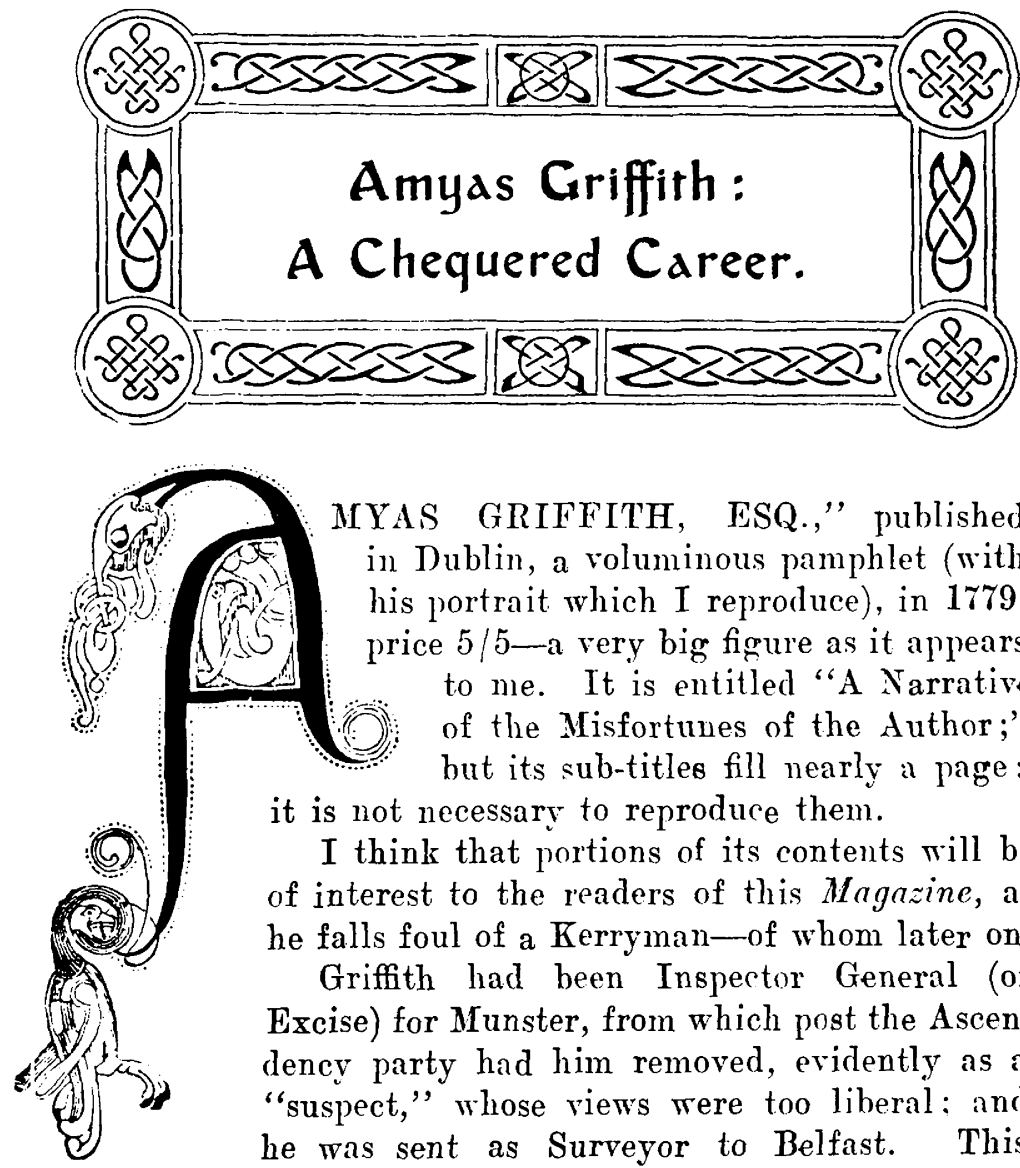

MYAS GRIFFITH, ESQ.," published in Dublin, a voluminous pamphlet (with his portrait which I reproduce), in $\mathbf{1 7 7 9}$, price $5 / 5-$ a very big figure as it appears to me. It is entitled "A Narrative of the Misfortunes of the Author;" but its sub-titles fill nearly a page: it is not necessary to reproduce them.

I think that portions of its contents will be of interest to the readers of this Magazine, as he falls foul of a Kerryman-of whom later on. Griffith had been Inspector General (of Excise) for Munster, from which post the Ascendency party had him removed, evidently as a "suspect," whose views were too liberal: and he was sent as Surveyor to Belfast. This change was, from a pecuniary point of view, practically reducing him to the ranks, and from this transfer he dates all his troubles. He appears to have been then a Protestant of too pronounced views with regard to Catholic Emancipation when he went north; and to use a slang phrase, he was not long in Ulster "before he put his foot in it"-as Sir Boyle Roche might say.

Richard, Bishop of Cloyne, had issued some violent Ascendency tracts, "supposed to be unanswerable," he says, "and provoked by the flummery with which he was bedaubed from top to toe, I entered the lists, and had the happiness to reflect that $I$ proved a friend in need to my country and humanity. I may say $I$ was led on, as a natural conse- 
quence of having undertaken the defence of my Roman Catholic brethren."

As a matter of fact he put a rod in pickle for himself, which his subsequent tergiversations gave the enemy an

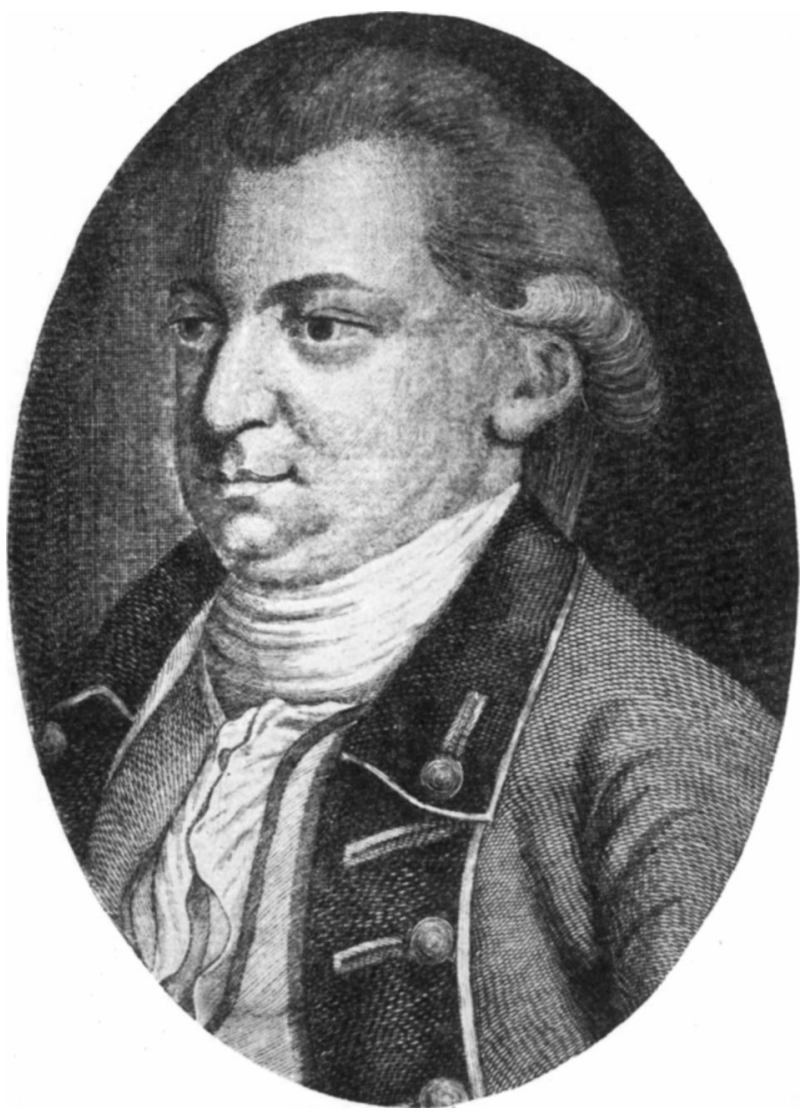

AMYAS GRIFIITH, ESQ.

excuse for wielding to some purpose, and to his utter undoing; the fact being that when he exchanged Munster for Ulster, he failed to realise that the social atmosphere was altogether different. He was at bottom an opportunist, who thought himself clever, but didn't see beyond his nose, 
and "hedged" when he should have stood his ground. 'I'he man's instincts were right enough at the start if he had the courage to stick to them; but he had no moral stamina, and when he came to grief he found himself friendless and unpitied.

The weakness of the man is shown by his own statement. "Upon my arrival here, with my family, early in May, 1780, from a province where I was adored by all degrees and ranks of people, and where every compliment, civility and respect were paid to my wife and children, I took it into my head that a particular class of people who should have been the first to pay us attention, being for the most part revenue officers and the agents and dependents of Lord D__ [Donegall], had treated me and my family with great disrespect." In fact he got the cold shoulder, and in order to counteract the feeling against him he began to trim, and founded a lodge with the assistance of a Mr. Seward, "the members for the most part being freemasons."

When he blossomed out as an Orangeman, he says: "I thought they had repented of their ill-treatment of me, and really for a time they pretended to make reparation; and I, on my side, did all in my power to make myself agreeable to them and useful to the town in general." He found on reading over the Lagan Act of Parliament, of which $I$ know nothing, that "English malt liquors were as subject to the local tax as Irish, and I enforced the same-which was absolutely a protecting duty to our Irish beer and ale, and which had been shamefully neglected for upwards of thirty years by all my predecessors, and this alone was sufficient (or should be) to render me popular, and to gain respect and friendship from every party."

His prospects seemed to be brightening up. "The brewers of Dublin sent me several hogsheads of porter as presents; and the brewers of Belfast a silver cup. Mr. P.— [George McCartney Portis?], Lord D—_s agent told me at his own table, that his Lordship would himself give me a proper cup of thanks (meaning a very handsome present), so soon as he was informed of the particular service I had been to the Lagan Navigation, the breweries 
of his town, and the kingdom in general; and that he, Mr. $\mathbf{P}$ __ would take special care to represent the matter to his Lordship." Things began to look exceedingly promising for Amyas; so much so indeed, that in order to still further ingratiate himself he, having the columns of the Dublin "General Evening Post" at his disposal, trumpeted forth the perfections of his Lordship at such a rate that he left him not a single foible or blemish-not even a hobby to get astride on.

Soon afterwards when Lord Donegall arrived in Belfast, "it was resolved that the principal people of the town should in a body, with an able orator, the facetious Mr. G[? Thomas Gregg] at their head, wait on his Lordship and pay him their devoirs and respects; and I of course as a gentleman and housekeeper, went with the crowd. We were introduced in pairs, as ·we entered, by $\mathrm{Mr} . \mathrm{P}-$," But, dreadful to relate, Amyas and his friend A- S[Allen Searson, a rich brewer] had to find their way in without an introduction by his Lordship's agent, Mr. P-. Subsequently his eyes were opened as to the treachery and double-dealing of Mr. P- and all and every creature about Lord D__, "which," he says, "irritated me so exexceedingly, that I was determined at the hazard of my life, and all I was worth, to oppose Lord $\mathrm{D}$ - and his emissaries in everything they took in hands, and so I really did from that day forth." 'This resolve to throw over the Ascendency party and revert to the Nationalists whom he had deserted, was the cause of his downfall; and this not because he took the step, but because atter he had taken it he was fooled into an effort to retrace it.

At the Carrickfergus election in 1784, he had the temerity first to offer himself as the popular candidate, "agin the Government," withdrawing in favour of his friend Cunningham, who won the seat-Amyas being very prominent in the business of the election. The result he says, "to a fellow so fired with the seeds of resentment and patriotism, as I then was, had ample recompense." But his triumph was of short duration. A petition was lodged and Cunningham was unseated; and an indictment framed 
against all the members of a Club in Lisburn, of which Amyas was one, on account of their interference at the election, and they were all summoned to appear before a Committee of the House of Commons, which was adjourned from April to August. This gave Amyas time to reflect, and he came to the conclusion that the party-coloured feather in his cap, of which he was recently so proud, had better, as a matter of expediency, give place to a white one.

He ratted with all speed. "After the adjournment," he goes on to say, "Mr. J- P-, an attorney [? John Pollock], agent to the lordly party, paid me frequent visits. He was a member of the Orange Lodge of which I was the founder and past master, and pretended much disinterested friendship for me. He highly reprobated my late proceedings, and told me that were it not for the influence of Lord H-_ [? Hillsborough] I would have been dismissed; that, however, if I altered my mode of acting and quit the damned party (as he was pleased to call them) that I then was of, he had hopes that I would have something handsome done for me. He also wished that I should withdraw myself from the Lisburn Club, and publish as reasons for so doing 'that they were growing turbulent and licentious and dangerous, etc., etc.;' but I told him with a proper steadiness that 'if the Chief Commissioner's place were offered me for subscribing to such a paper, and the gallows the consequence of my refusal, I would prefer the latter, sooner than render myself so execrable a villain'; but, at the same time, I told him that to oblige and please Lord H-, I would no longer attend the Club, but would withdraw myself by degrees from the Independent interest-that I would, in future, have nothing to do with politics, nor ever write on either side of the question; and that I would alone mind and attach myself to the business of my profession, and do my duty in that state of life unto which it had pleased God to call me."

Doubtless, he chortled at his cleverness, particularly as some time before this he had written a prologue to a play, at the Belfast Theatre, on a special Masonic Night, and attended with the brethren of the Orange Lodge, No. 257- 
a fact which now, he had no doubt, would be imputed to him for righteousness. But the astute attorney was too many for him, and had got him in the toils when he least suspected. On the 24th June, 1784, Amyas tells how he dined at the Orange Lodge in the evening, and met Lord $\mathrm{H}$ - [Hillsborough] and had a long conversation with Lord K- [Kilwarlin, his son], "who both seemed much hurt at my conduct, declaring that I must inevitably be dismissed or removed. I confessed that I had behaved hitherto very inconsistently, but that my subsequent conduct should make ample atonement, that I had no antipathy to government of $\mathrm{His}$ Majesty; my grandfather (by my mother) was a major in the army, my father's father, secretary to the Commissioners of the Revenue, and my father himself a surveyor; that what I had done was partly in opposition to some of the Commissioners who had used me most basely," and a lot more to the same effect, which I need not quote. Then he goes on, "I solemnly declared, however, that I would turn over a new leaf, and that he. (his Lordship) should never have further cause to complain of me."

Then he makes the following admission in his pamphlet: "Immediately after this, to turn as I hoped the impending ruin from me, and avert destruction from myself and innocent family, I commenced court writer, and dashed away a little at the poor Roman Catholics, by which means I drew upon myself the vengeance of the country papers. In short, I got myself completely abused, and thought thereby I had weathered the storm, and that I was once again safe moored, and in harbour." He does not appear to be a bit ashamed of himself, but, on the contrary, boasts of being a man of honour! The storm, however, burst and wrecked him when he thought himself secure.

Attorney John Pollock hadn't done with him yet. It was determined that the petition against Cunningham should go on, and that the versatile Amyas must attend as a material witness. "I entreated him to overlook me, and observed that my attendance might prove my destruction. I declared this to him as a Freemason, and conjured him by every tie on earth not to have me called upon, as the con- 
sequences would be my dismissal from my employment, which was better than $£ 400$ per annum, and the only support I had for my poor family. Mr. P- then, laughing at my apprehensions, assured me that if $I$ did not answer such questions as should be put to me without embarrassment or hesitation, I would undoubtedly be turned out; my stiffness would be of no avail.,"

There was a lot of talk. This J-_ P-, alias John Pollock, was in fact no other than the Crown Prosecutor for Leinster, who was a prominent figure not only then, bur subsequently all through the '98 rebellion and the rising in 1803. It was, in fact, he who "squared" that scoundrel MacNally, to Robert Emmet's undoing. "He worked his way," says Madden, "by dirty dealings with sples and informers, into the confidence of the Executive, and into the disreputable office of secret legal agent of government, engaged in terrifying prisoners into confessions, applying secret service money to the purposes of corrupting witnesses and tampering with jury panels." Griffith's shallow pomposity did not take in the astute attorney, who "played" his fish cleverly till he got what he wanted-an incriminating confession from this slippery customer, to the effect that he had helped Mr. Cunningham "with every influence. I could make use of, not only as a private gentleman, but as a surveyor of taxes." Then the attorney held out a tempting bait which the gudgeon swallowed. Lord $\mathrm{D}-$, he said was to do a lot for Amyas, "but thought it better to defer establishing me until the trial of the petition should be over, and that then I might rely on having something vastly superior done for me, and my fortune and that of my children made; otherwise nothing but ruin and destruction awaited me." The astonishing part of the business is that he had no suspicion of the game that was being played. The Irickster was completely tricked.

At the trial in February, 1785, he was the first witness called, "when I unfortunately confessed that I had used every exertion in my power in favour of $\mathrm{Mr}$. Cunningham, not only as a private gentleman, but as a revenue officer." After giving himself away to the full satisfaction of the 
Ascendency party he left Dublin "as soon as possible, without even so much as calling for my expenses, because I did not chuse to put either party to any cost or trouble (!). I was apprehensive that I stood but upon a sandy bottom."

His foreboding was right, he was up against a situation that he did not bargain for; the enemy was not yet done with him. After Cunningham, through his evidence, was unseated, he was called upon by Mr. P_, on behalf of the new candidate, the Honble. Sergeant Hewitt, to take an active part in the election, which he actually did, going to Carrickfergus for the purpose; $\mathrm{Mr}$. P__ giving him to understand that when the fight was over Lord $\mathbf{K}$ - and others were to do wonders for him. When he had been made use of and fooled to the top of his bent, they left him to his fate and the tender mercies of the most powerful and relentless man in Ireland-the Right Honble. Mr. B-d [Beresford]. This great and notorious man-brother of Lord Waterford, and father of the no less notorious John Claudius of ' 98 celebrity, happened to be, in conjunction with his many other appointments, Chief Commissioner of Excise, and did not leave the worthy Amyas long in suspense. The following letter cleared the air:-

"Sir,-The Board of Commissioners having read over the minutes taken before the Committee of the House of Commons on the trial of the Carrickfergus petition, and it appearing to them from the depositions of Amyas Griffith, Surveyor of Excise in your district, that he is a very improper person to serve in any office of the revenue. They therefore dismiss him and appoint John Sutton, eldest Assistant Examiner to succeed him. Sutton's salary to commence from the 25th instant.

"To Robert Kyle, Esq.,

"Signed by order

"Vaughan Montgomery.

"Collector of Lisburn."

Then he took to writing pamphlets, from which one extract will be enough for the reader. "Almighty God! what were my feelings-very near three hundred pounds 
in debt, robbed of my employment for no cause on earth but being an honest man (!) My once real friends exasperated at my late conduct in deserting their cause, and flying to the standard of veuality; no prospect open and nothing to look forward to but a cruel fate-the grave; with a mind tortured even to madness, sometimes looking at my family and sometimes at my pistols, anxious to hasten out of an ungrateful world," etc., etc. But he hadn't the smallest idea of suicide any more than a spark of religion or sense of honour, but he was an adept at printing, and possessed a portable press, which he had used with good effect in printing posters for his friend Cunningham at the Carrickfergus election in 1784, and afterwards used for the other side at the following election after Cunningham was unseated. This press he now utilised in his own behalf. He bombarded Lord Hillsborough, Lord Kilwarlin, Attorney Pollock and others.

On April 27, 1785, the latter wrote to say that he was to get the appointment of Barrack Master of Belfast, and the Dublin "Evening Post" stated that he was indebted to Lord Hillsborough for this piece of good fortune, whereupon he printed and circulated a gushing poetical panegyric on bis Lordship. But, alas! he didn't get the post. It was given to $\mathrm{A}-\mathrm{r} \mathrm{B}-\mathrm{n}$ [? Arthur Bunton], a friend of Lord D__'s agent. Amyas in despair gave vent to his outraged feelings. "Circumvented! Oh, my poor heart, why don't you burst in pieces? Oh, horrid, horrid, horrid! $\mathrm{Oh}$, God of Heaven, take pity upon a poor man, who, whilst he had it, felt for all your creatures in.distress. All is lost, and in the shipwreck, one only jewel have I saved-my Honor." $\mathrm{He}$ was now destitute, and when he attempted to borrow a guinea or two he was repulsed, and his acquaintances turned their backs upon him, as though he were "guilty of murder, treason, robbery." "I have suffered the torture of the damned," he says. "As for Mr. Cunningham, whom I lost my all for, he wouldn't speak to me! Oh! how true are my late dear friend, Counsellor Spring's lines:- 
" 'When fortune is smiling what crowds will appear, Their kindness to offer and friendship sincere;

But change but the prospect and point out distress, No longer to court you they'll eagerly press.'

"All that remains for me are distraction, sorrow, shame and death!'-and so on.

I presume this late dear friend Spring was a Kerryman. It was under the belief that Amyas himself was a son of "the Kingdom" that I took an interest in his career, and I based the assumption on a passage in a letter of his addressed to "Dominick Trant, Esq., relative to the latter's attack on the peasantry of Munster, and the death of Sir John Colthurst, Bart.,"' in which he says:-“Oh, Dominick! when you strenuously urged the case of the weaker party before me at the memorable and tedious trial of the 'Christina,' in the very capital of our dear Kingdom of Kerry, where both of us made our first debut," etc., etc. This paragraph had, I suppose reference to the excise trial in Tralee about a ship named the "Christina." But the worthy Amyas was not, I am glad to say, a Kerryman; he was born in Roscrea, in 1746. Trant was a well-known barrister-a scion of the Dingle family - whose pamphlet resulted in a duel with Sir John Colthurst, whom he killed. Amyas begins his attack thus:-

"Dear Dominick,

"As I have had the honor of knowing you since I was four years old, and as an old school fellow ${ }^{1}$ and an intimate acquaintance, permit me to tell you, sir, that though you have advanced yourself to wealth and consequence, by taking one side of the question, I (on the contrary) have ruined myself by unfortunately and unthinkingly taking the other."

In the number for March, 1914, of this Magazine, there is an interesting article on the Trant Family, with a portrait of Dominick, which may be compared with Griffith's description of him. "Your rise in life, my friend, was more

\footnotetext{
* It appears from a contemporary attack on Griffith that the school was kept by a Mr. Young in Tralee.
} 
owing to chance than any exertion of your own; your handsome figure, good face, and elegant address."

A statement in this article on the Trants may give a clue to the animosity of Griffith towards Dominick. It says that the latter "made a lot of money by his profession, and appears to have done very good business as counsel for the smuggling gentlemen of the South. In a case where a ship and an valuable cargo were at stake, he got 50 guineas on his brief, and seven guineas a day from the moment he slipped into his post chaise at the door of his town house." Probably this was the "Christina" case above mentioned, and tried in Tralee, where Amyas, no doubt, gave himself airs as Commissioner of Excise.

Amyas was for a while a private in the Tralee Royal Volunteers, commanded by Sir Barry Denny, "when they marched," so he says, "to Iveragh, and brought Captain Lunt, brother-in-law to Paul Jones, with sixteen American prisoners to Tralee.

As the remaining incidents of his career were not specially connected with Kerry-though interesting in themselves -I must not take up too much space in recounting them. I have had to dig out the facts from the periodicals and pamphlets of the period. Exhaw's Magazine says of him :"He does not appear so sunk in vice as to prevent our seeing his misfortunes with compassion, nor so elevated in virtue as to totally to escape censure." This is letting him down easy.

I have stated that he was born in Roscrea in 1746. On various occasions he brags much about his pedigree, and his relatives, the Agars, the Wemys', the Walsh's, the Wandesford's the Bushes, Sir John Lowther, Sir Edward Trotter, etc., etc., and my investigations lead to the conclusion that his claims are justified. The curious Christian name, Amyas, he got from the Bushe family. His father was Surveyor of Excise, and his mother a daughter of Capt. Maxwell-a connexion of Lord Wandesford. When about six months old he was brought to Tralee, and subsequently was educated there till about 1760, where Dominick Trant was, as already stated, his schoolfellow. In that year he 
came to Dublin, and entered Trinity College. Here his conduct was so bad that he was rusticated. He made his way to London, and entered at the Temple to study for the law; but ran such a rig that in less than six months he found it expedient to return to Dublin, and at the age of seventeen launched out as an author, wrote poems and a play called "The Swaddler," in which he satirised a great contemporary, John Wesley, and gained both notoriety and money, the latter he expended in 1762 on the purchase of a commission in the 2nd Regiment of Foot, and immediately plunged into the wildest extravagance. In 1763 he had to sell out to pay his creditors, and then found himself shunned by all his reputable relatives. One of them, however, Gervase Parker Bushe (whose wife was a sister of Henry Grattan) procured him the post of Supernumary Guager at Wexford. Oh! what a falling off was there! But necessity drove him to accept. He was, however, too volatile to profit by his experiences, or to listen to the dictates of prudence, and immediately made love to and married a Miss Radford of Wexford, niece of the Mayor of that town. She brought him some money, and with it he started a shop; but before twelve months he had failed in business and had fought a duel, in a private room, with another Guager, whom he wounded, so that Wexford became too hot for him, and he managed to get a transfer to Tralee, where he found himself among old friends, who received him and his wife and infant daughter with Kerry hospitality. This was in 1765. Here his stay was short, as in 1766 we find him shifted to Fethard-whether at his own request or not I am unable to say, but probably against his will. In a contemporary pamphlet his pecuniary position is discussed. "His salary in Fethard was about sixty pounds a year, to this he added about forty pounds more by his pen, and having some knowledge of law, he set up as an attorney, which augmented his income to about a hundred and forty a year, to which his father added another forty." He held on in Fethard for several years-having apparently done some good work. From Fethard he was transferred to Skibhereen, and made Inspector of Kinsale and Surveyor 
of Baltimore. By his zeal and good conduct he advanced himself in the esteem of the Government, so much so, that he was appointed Inspector General for the Province of Munster, and Sub-Commissioner for every district in it, with a good salary, an allowance for travelling expenses, and a deputy to act for him at Baltimore. His energy was great, and he succeeded in discovering many frauds, and making big seizures-in one case amounting to over five thousand pounds in value.

He was now rich and powerful_- "at the top of the tree," when in 1779 he came a cropper. Without going into details it will suffice to say that his course of conduct had been so reprehensible, and had at last caused so much scandal, that it was found necessary to remove him from his post of Inspector-General and reduce him to the rank of Surveyor. So he dropped at once from sixteen hundred a year to sixty-five. Moreover, a bill for damages being filed against him at the suit of an injured husband, in the matter which led to his downfall, he had to fly from Cork on foot at four o'clock in the morning with three guineas in his purse, and two shirts in his pocket. After walking eight miles he was picked up by a passing chaise and got a "lift" as far as Ballyporeen, from thence he got to Callan, afterwards to Kilkenny, and thence by stage-coach to Dublin, where he hid for some days, while doubtless he got powerful friends to pull him out of the mud and set him on his feet, for we find him soon after transferred to Belfast in an official capacity. I have related above his extraordinary career while there, and its termination. He returned to Dublin, and through the influence of Sir William Osborne was appointed Examiner of Excise. But this advancement proved to be his undoing, for he found himself among boon companions once again, and ran riot accordingly. Disaster followed, and to extricate himself from the toils of dire necessity he had recourse to his pen, and turned against the Government. This made him popular with the mob, and on this wave of popularity - when party spirit ran high-he hoped to retrieve his fallen fortune, and even to rise to eminence. He actually had the audacity to aspire to the 
representation of the city in room of the great Dr. Lucas; but foiled in this ambitious scheme, he sank to the lowest depths of literary infamy; and in his desperate shifts he redoubled his attacks upon the Government, and not only that, but he started a paper which has never been equalled, or even approached, for scurrility and filth. It was called "The Monitor, or New Freeman," and set itself to invent the most atrocious scandals and to connect them by initials with reputable persons, male and female, not only in Dublin but in the provinces. So cruel were some of the insinua. tions that the death of more than one over-sensitive lady was said to be traced to this diabolical print. The editorship could not legally be brought home to him, and the name of the printer did not appear. Something had to be done, so the Irish Parliament passed an Act making it compulsory that the proprietors of all newspapers should be registered, printer's name recorded, and a stamp tax instituted. This step killed the filthy rag after a twelve month's career, and Amyas was "hoist by his own petard."

How he managed to subsist for some time after this it would not be easy to discover, but we know that he suffered the pinch of poverty, and was in dire distress, with a wife, son and daughter depending on him. In 1792 he was a prisoner for debt in the Marshalsea. The proprietor of Crow Street Theatre gave him a "benefit" night on his promising by advertisement not to make any other demands on public charity. He died on 24th August, 1801, in St. James Street, after a most extraordinary career. The man's moral fibre was of the weakest, and he had no sense of honour; but he had no lack of physical courage, fought several duels, and in the columns of his scurrilous paper expressed himself ever ready to give "satisfaction" to anyone seeking it according to the then fashionable rules of duelling.

\section{J. F. FULLER.}

\section{Glashnacree, Kenmare.}

